\title{
Enhanced Phosphatase Activity Attenuates $\alpha$-Synucleinopathy in a Mouse Model
}

\author{
Kang-Woo Lee, ${ }^{1}$ Walter Chen, ${ }^{2}$ Eunsung Junn, ${ }^{1}$ Joo-Young Im, ${ }^{1}$ Hilary Grosso, ${ }^{1}$ Patricia K. Sonsalla, ${ }^{1}$ Xuyan Feng, ${ }^{3}$ \\ Neelanjana Ray, ${ }^{3}$ Jose R. Fernandez, ${ }^{3}$ Yang Chao, ${ }^{3}$ Eliezer Masliah, ${ }^{4}$ Michael Voronkov, ${ }^{3}$ Steven P. Braithwaite, ${ }^{3}$ \\ Jeffry B. Stock, ${ }^{2,3}$ and M. Maral Mouradian ${ }^{1}$ \\ ${ }^{1}$ Center for Neurodegenerative and Neuroimmunologic Diseases, Department of Neurology, University of Medicine and Dentistry of New Jersey-Robert \\ Wood Johnson Medical School, Piscataway, New Jersey 08854, 2 ${ }^{2}$ epartment of Molecular Biology, Princeton University, Princeton, New Jersey 08544, \\ ${ }^{3}$ Signum Biosciences, Monmouth Junction, New Jersey 08852, and ${ }^{4}$ Department of Neurosciences, School of Medicine, University of California-San Diego, \\ La Jolla, California, 92093
}

$\alpha$-Synuclein ( $\alpha$-Syn) is a key protein that accumulates as hyperphosphorylated aggregates in pathologic hallmark features of Parkinson's disease (PD) and other neurodegenerative disorders. Phosphorylation of this protein at serine 129 is believed to promote its aggregation and neurotoxicity, suggesting that this post-translational modification could be a therapeutic target. Here, we demonstrate that phosphoprotein phosphatase 2A (PP2A) dephosphorylates $\alpha$-Syn at serine 129 and that this activity is greatly enhanced by carboxyl methylation of the catalytic $\mathrm{C}$ subunit of PP2A. $\alpha$-Syn-transgenic mice raised on a diet supplemented with eicosanoyl-5-hydroxytryptamide, an agent that enhances PP2A methylation, dramatically reduced both $\alpha$-Syn phosphorylation at Serine 129 and $\alpha$-Syn aggregation in the brain. These biochemical changes were associated with enhanced neuronal activity, increased dendritic arborizations, and reduced astroglial and microglial activation, as well as improved motor performance. These findings support the notion that serine 129 phosphorylation of $\alpha$-Syn is of pathogenetic significance and that promoting PP2A activity is a viable disease-modifying therapeutic strategy for $\alpha$-synucleinopathies such as PD.

\section{Introduction}

$\alpha$-Synuclein ( $\alpha$-Syn) is a key protein in Parkinson's disease (PD) and other $\alpha$-synucleinopathies due to genetic linkage and its aggregation in Lewy bodies and Lewy neurites, the pathological hallmarks of disease (for review, see Goedert, 2001). The oligomerization and subsequent fibrillization of $\alpha$-Syn are believed to play a major role in neuronal dysfunction and death. Postmortem human brain studies have shown that the protein is selectively and extensively phosphorylated at serine 129 in synucleinopathy lesions of PD and dementia with Lewy bodies (Fujiwara et al., 2002; Neumann et al., 2002; Anderson et al., 2006). Hyperphosphorylated and misfolded $\alpha$-Syn also accumulates in affected neurons of transgenic mice that express human $\alpha$-Syn (Neumann et al., 2002) and leads to increased $\alpha$-Syn toxicity in Drosophila (Chen and Feany, 2005). In vitro,

\footnotetext{
Received Dec. 14, 2010; revised March 10, 2011; accepted March 16, 2011

Author contributions: J.B.S. and M.M.M. designed research; K.-W.L., W.C., J.-Y.I., H.G., P.K.S., X.F., N.R., J.R.F., Y.C., and M.V. performed research; E.M. contributed unpublished reagents/analytic tools; K.-W.L., E.J., J.-Y.I., S.P.B., J.B.S., and M.M.M. analyzed data; S.P.B., J.B.S., and M.M.M. wrote the paper.

J.B.S. is a founder of Signum Biosciences, Inc., which employs the indicated coauthors.

This work was supported by a grant from Signum Biosciences to M.M.M., who is the William Dow Lovett Professor of Neurology. J.B.S. is supported in part by a grant from the American Parkinson Disease Association. We thank Teresa Chan for technical assistance and Yulia Frenkel for manuscript preparation.

This article is freely available online through the J Neurosci Open Choice option.

Correspondence should be addressed to Dr. M. Maral Mouradian, Department of Neurology, University of Medicine and Dentistry of New Jersey-Robert Wood Johnson Medical School, 683 Hoes Lane West, Room 180, Piscataway, NJ 08854. E-mail: Mouradian@umdnj.edu.

DOI:10.1523/JNEUROSCI.6513-10.2011

Copyright $\odot 2011$ the authors $\quad 0270-6474 / 11 / 316963-09 \$ 15.00 / 0$
}

phosphorylation of $\alpha$-Syn at serine 129 promotes its oligomerization and fibrillization (Fujiwara et al., 2002). Therefore, moderation of phosphorylation and aggregation of $\alpha$-Syn is hypothesized to be of therapeutic value.

Levels of $\alpha$-Syn phosphorylation are regulated by a balance between rates of phosphorylation by protein kinases and dephosphorylation by phosphoprotein phosphatases. Phosphorylation at Ser 129 can be mediated by multiple kinases including casein kinases (Ishii et al., 2007), G protein-coupled receptor kinases (Pronin et al., 2000), and Polo-like kinases (Inglis et al., 2009; Mbefo et al., 2010), while the dephosphorylating enzyme has received little attention. Phosphoprotein phosphatase 2A (PP2A) is the primary serine/threonine phosphatase in the brain, accounting for over $50 \%$ of total brain Ser/Thr phosphatase activity (Strack et al., 1997). It exists functionally as trimeric holoenzymes whose assembly and activity are regulated by reversible carboxyl methylation of the catalytic $\mathrm{C}$ subunit, which in complex with a structural A subunit promotes association of the "AC" dimer with regulatory B subunits that confer substrate specificity (Bryant et al., 1999; Tolstykh et al., 2000; Wu et al., 2000). The methylation status of PP2A is governed by the opposing activities of a PP2A-specific methyltransferase (PPMT) and a PP2A-specific methylesterase (PME-1) (Lee and Stock, 1993; Lee et al., 1996; Ogris et al., 1999).

Here, we show that activation of PP2A stimulates the dephosphorylation of $\alpha$-Syn in vitro and in vivo and that the resulting reduced level of $\alpha$-Syn phosphorylation relieves the neuropathology and behavioral deficits of a transgenic mouse model of $\alpha$-synucleinopathy. 


\section{Materials and Methods}

Reagents. $\mathrm{PP} 2 \mathrm{~A} \mathrm{AC}$ dimer and $\mathrm{AB} \alpha \mathrm{C}$ trimer were expressed and purified using previously published protocols (Tolstykh et al., 2000; Xing et al., 2006). PPMT and PME-1 purifications were performed as described previously (Xing et al., 2008). PP1c $\alpha$ (rabbit muscle, recombinant, Escherichia coli) was purchased from Calbiochem. Eicosanoyl-5-hydroxytryptamide (EHT) was synthesized at Signum Biosciences. S-[methyl- $\left.{ }^{3} \mathrm{H}\right]$-Adenosyl-L-methionine $\left(\left[{ }^{3} \mathrm{H}\right]-\mathrm{SAM}\right)$ was purchased from PerkinElmer. Antibody sources are as follows: anti$\alpha$-synuclein and anti-iNOS (inducible nitric oxide synthase) (BD Transduction Laboratories); anti-human $\alpha$-synuclein (Zymed); antiphospho ${ }^{\text {ser129 }}-\alpha$-synuclein (Wako); anti-demethylated PP2A, antiPP2A-B, and anti-PP2A-C (Millipore); anti-HDAC1 (histone deacetylase 1), anti-MAP2 (microtubule-associated protein 2 ), and anti-c-fos (Santa Cruz Biotechnology); anti-GFAP (glial fibrillary acidic protein) (DakoCytomation); and anti-CD11b (AbD Serotec). The anti-demethylated PP2A antibody $4 \mathrm{~b} 7$, which is critical for these studies, has well characterized specificity (Yu et al., 2001) and, in our hands, demonstrates selective recognition for demethylated over in vitro methylated PP2A.

PP2A phosphatase activity toward $\alpha$-synuclein. C-terminal His -tagged $_{6}$ human $\alpha$-synuclein was cloned into pET21b vector and expressed in $E$. coli BL21DE3 cells. Affinity (nickel-nitrilotriacetic acid, Sigma-Aldrich) and anion exchange chromatography (Mono Q, GE Healthcare) was used to purify protein. Phosphorylation was performed by incubation with casein kinase 2 in $20 \mathrm{~mm}$ Tris, $\mathrm{pH} 7.5,100 \mathrm{~mm} \mathrm{NaCl}, 10 \mathrm{~mm}$ DTT, and $5 \mathrm{mM} \mathrm{MgCl}_{2}$ buffer with $2 \mathrm{~mm}$ ATP overnight at $37^{\circ} \mathrm{C}$. Phosphorylated $\alpha$-synuclein was purified using anion exchange chromatography (Mono Q, GE Healthcare).

To assay for phosphatase activity toward pS129 $\alpha$-Syn, PP1 or PP2A (methylated or demethylated) were serially diluted to different concentrations and then incubated with $1.1 \mu \mathrm{M}$ phosphorylated $\alpha$-Syn in buffer containing $50 \mathrm{~mm}$ MOPS [3-( $N$-morpholino)-propanesulfonic acid], $\mathrm{pH} 7.2,5 \mathrm{~mm}$ DTT, and $100 \mu \mathrm{M} \mathrm{Mn}{ }^{2+}$ at $30^{\circ} \mathrm{C}$ for $30 \mathrm{~min}$. The reactions were stopped by adding $5 \times$ SDS sample buffer. Samples were resolved by SDS-PAGE, transferred onto nitrocellulose membranes, and incubated with anti-pS129 $\alpha$-Syn antibody overnight at $4^{\circ} \mathrm{C}$. Secondary anti-rabbit antibody was applied and blots developed using ECL Plus (GE Healthcare Life Sciences). Membranes were scanned with a Storm Scanner (GE Healthcare Life Sciences).

PP2A demethylation assay. Recombinant, methylated human PP2A AC dimer $\left(\left[{ }^{3} \mathrm{H}\right]\right.$-methyl-PP2A) was freshly prepared by incubating PP2A, PPMT, and $\left[{ }^{3} \mathrm{H}\right]-S A M$ at $37^{\circ} \mathrm{C}$ for $1 \mathrm{~h}$. Unreacted SAM and PPMT were removed by ion exchange chromatography. EHT was preincubated with $10 \mathrm{~nm}$ PME-1 for $10 \mathrm{~min}$, followed by addition of $50 \mathrm{nM}\left[{ }^{3} \mathrm{H}\right]$ methyl-PP2A. Reaction was allowed to proceed for $30 \mathrm{~min}$ at room temperature and was stopped by addition of $10 \%$ TCA and $\sim 0.5 \mu \mathrm{g}$ of BSA. Reactions were centrifuged for $10 \mathrm{~min}$ at $12,000 \mathrm{rpm}$ to pellet the precipitated protein. An aliquot of the supernatant was added to scintillation fluid (Ecoscint, National Diagnostics) and counted on a scintillation counter (Beckman) to determine the amount of $\left[{ }^{3} \mathrm{H}\right]$-methanol liberated by PME-1.

Cell culture and treatment. SH-SY5Y cells stably overexpressing $\alpha$-Syn were cultured as described previously (Kanda et al., 2000). For PP2A knockdown experiments, these cells were transfected with small interfering RNAs (siRNAs) for $72 \mathrm{~h}$ at $100 \mathrm{~nm}$ final concentration using Lipofectamine 2000 reagent (Invitrogen). SMARTpool siRNAs of nontargeting, PP2A C subunit $(\mathrm{C} \alpha)$, or $\mathrm{B} \alpha$ subunit were obtained from Thermo Scientific Dharmacon. Primary neuronal cultures were prepared from embryonic day 18 rat embryos by standard procedures. Briefly, cortical neurons were dissociated by brief mechanical trituration and suspended in full neurobasal medium supplemented with B27 (Invitrogen), penicillin, streptomycin, and $2 \mathrm{~mm} \mathrm{~L}$-glutamine. After 7 days in vitro, neurons were treated for $4 \mathrm{~h}$ with serial dilutions of EHT in ethanol ( $1 \% \mathrm{v} / \mathrm{v}$ final concentration).

Animals and EHT administration. All animal procedures were approved by the University of Medicine and Dentistry of New JerseyRobert Wood Johnson Medical School Institutional Animal Care and
A
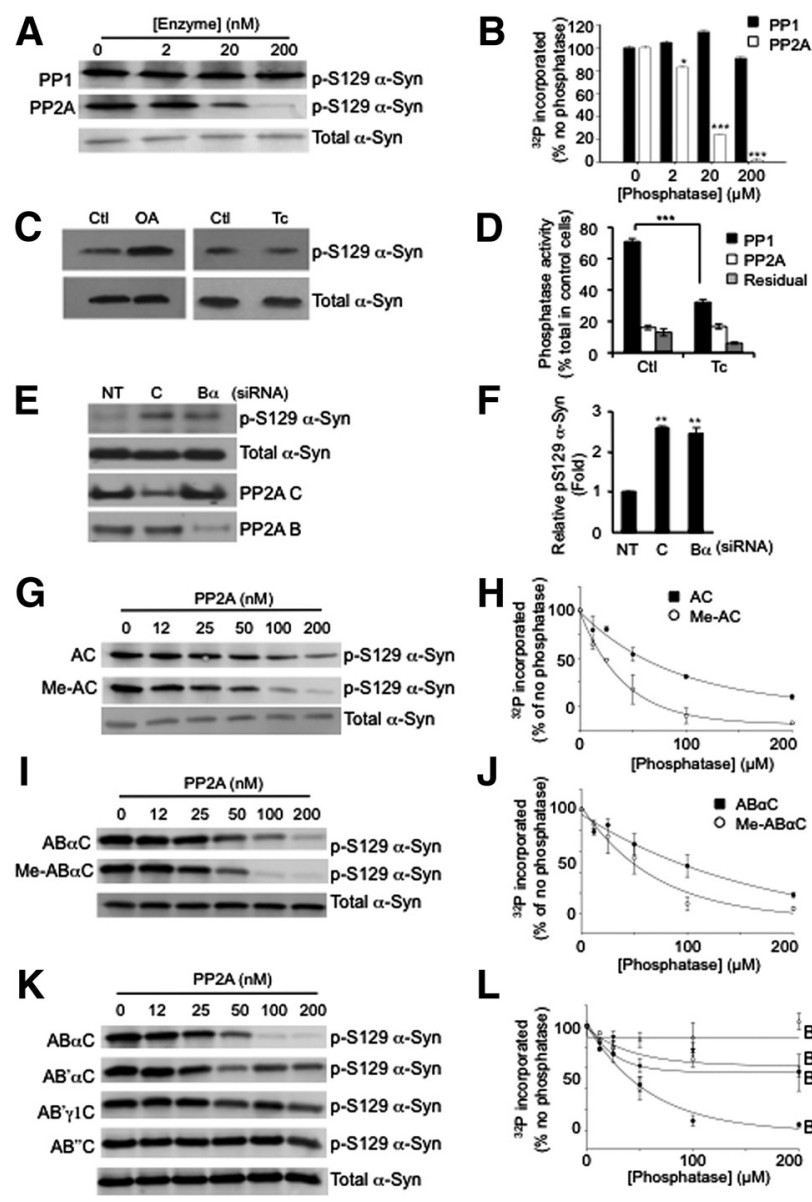

$\mathbf{F}$
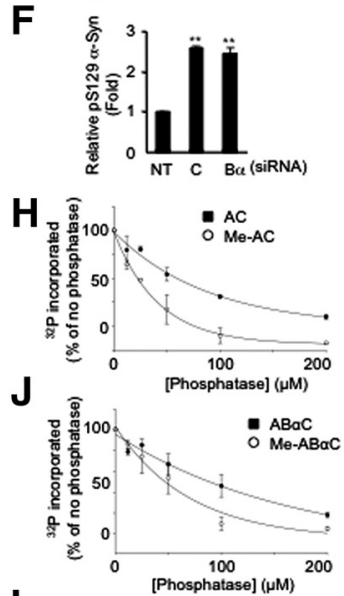

$\mathbf{L}$

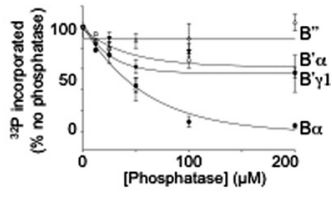

Figure 1. PP2A catalyzes the dephosphorylation of pS129 $\alpha$-Syn in a methylationdependent manner. $A$, In vitro dephosphorylation reactions performed by incubating phosphorylated $\alpha$-Syn with PP1 (top) or PP2A (middle) demonstrate that PP2A, but not PP1, dephosphorylates $\alpha$-Syn in a concentration-dependent manner. $B$, Quantification of the effects of PP1 and PP2A on $\alpha$-Syn dephosphorylation. ${ }^{*} p<0.05$; ${ }^{* * *} p<0.005$. C, Western blotting of lysates from SH-SY5Y cells stably expressing $\alpha$-Syn treated for $1 \mathrm{~h}$ with $250 \mathrm{~nm}$ okadaic acid (OA) or $1 \mu \mathrm{m}$ tautomycetin (Tc) with p-S129 $\alpha$-Syn antibody shows that inhibition of PP2A but not PP1 modulates $\alpha$-Syn phosphorylation (top). Total levels of $\alpha$-Syn are unaffected by OA or Tc treatment (bottom). Ctl, Control. D, Tautomycetin is active on PP1 in SH-SY5Y cells. Cells incubated with ethanol (control) or $1 \mu \mathrm{M}$ Tc for 20 min were lysed and in vitro dephosphorylation reactions were performed using ${ }^{32} \mathrm{P}$-labeled phosphorylase a. Activities are defined as follows: PP1, the fraction sensitive to $2 \mu \mathrm{M} 0 \mathrm{~A}$ but insensitive to $5 \mathrm{~nm} 0 \mathrm{~A} ; \mathrm{PP} 2 \mathrm{~A}$, the fraction sensitive to $5 \mathrm{~nm} \mathrm{OA}$; and residual fraction, insensitive to $2 \mu \mathrm{M} \mathrm{OA.}{ }^{* * *} p<0.005$. $E$, Knockdown of PP2A subunits results in increased p-S129 $\alpha$-Syn. SH-SY5Y cells expressing $\alpha$-Syn were transfected with siRNA of nontargeting (NT), catalytic ( subunit, or B $\alpha$ subunit. Cell lysates were subjected to Western blotting for p-S129 $\alpha$-Syn, total $\alpha$-Syn, PP2A C subunit, and PP2A B subunit. Representative data from three separate experiments are shown. $\boldsymbol{F}$, Quantification of p-S129 $\alpha$-Syn compared to total $\alpha$-Syn with knockdown of PP2A subunits. ${ }^{* *} p<0.01$. G, Western blots with pS129 $\alpha$-Syn antibody of in vitro dephosphorylation reactions performed by incubating phosphorylated $\alpha$-Syn with PP2A AC dimer (AC, top) or methylated AC dimer (Me-AC, middle) indicate that methylation increases the ability of PP2A AC to dephosphorylate $\alpha$-Syn at Ser129. $H$, Quantification of the effects of methylation of AC dimers on PP2A activity toward phosphorylated $\alpha$-Syn. I, Heterotrimeric assemblies of PP2A AB $\alpha$ C subunits ( $\mathrm{AB} \alpha \mathrm{C}$, top) increase activity to dephosphorylate $\alpha$-Syn subsequent to methylation (Me-AB $\alpha$ C, middle). J, Quantification of the effects of methylation of $A B \alpha C$ heterotrimers on PP2A activity toward phosphorylated $\alpha$-Syn. $\boldsymbol{K}$, Different regulatory B subunits strongly influence the ability of PP2A to dephosphorylate $\alpha$-Syn at Ser129. L, Quantification of the effects of B subunit composition on PP2A activity toward phosphorylated $\alpha$-Syn.

Use Committee and were performed according to the National Institutes of Health Guide for the Care and Use of Laboratory Animals. Male mice transgenic for human wild-type $\alpha$-Syn under the control of the Thy-1 promoter (Rockenstein et al., 2002), and wild-type littermates were 
housed two per cage under a $12 \mathrm{~h}$ dark-light cycle with ad libitum access to food and water. The transgenic line was maintained on the mixed C57BL/6-DBA/2 background by breeding transgenic females with wildtype males. Upon weaning, animals were placed on a diet containing $0.01 \% \operatorname{EHT}\left(n=13 \alpha-\right.$ Syn $^{\mathrm{Tg}}$, where Tg is transgenic; $n=10$ wild-type), $0.1 \% \operatorname{EHT}\left(n=12 \alpha\right.$-Syn ${ }^{\mathrm{Tg}} ; n=9$ wild-type) or control chow $(n=12$ $\alpha$-Syn ${ }^{\text {Tg; }} n=9$ wild-type). Mice were weighed and their food intake quantified weekly. Behavioral tests were performed every 3 months. At 9 months of age, animals were anesthetized, perfused with PBS, $\mathrm{pH} 7.4$, and the brains were quickly dissected. One hemi-brain was immediately frozen for Western blot analyses and biochemical assays, and the other hemi-brain was postfixed in $4 \%$ paraformaldehyde in $\mathrm{PBS}, \mathrm{pH} 7.4$, at $4^{\circ} \mathrm{C}$ overnight for immunohistochemical stains.

Behavioral tests. Sensorimotor behavioral assessments were performed at 3, 6, and 9 months of age. The rotarod test was performed using the automated TSE system. Mice were placed on the rod at a constant speed of $4 \mathrm{rpm}$ for $30 \mathrm{~s}$ and then tested with an accelerating speed of $0.2 \mathrm{rpm} / \mathrm{s}$ for a total of three trials. Latency to fall was measured for each trial, and the average of three trials was recorded. Nesting behavior was performed as described previously (Sager et al., 2010) by placing the animals in a new cage with a $5 \mathrm{~cm}$ tightly packed cotton square Nestlet (Ancare). Eighteen hours later, nest formation was rated by a blinded observer on a scale of 0 (nonshredded) to 5 (maximally shredded) (Deacon, 2006).

Western blotting and immunohistochemistry. For Western blot analysis, brain tissue was homogenized in $4^{\circ} \mathrm{C}$ radioimmunoprecipitation assay (RIPA) lysis buffer (50 mm Tris, $\mathrm{pH}$ 8.0, $150 \mathrm{~mm} \mathrm{NaCl}, 1 \%$ Nonidet P-40, $0.1 \%$ SDS, $0.5 \%$ sodium deoxycholate) containing phosphatase inhibitor cocktail set II (Calbiochem) and protease inhibitor cocktail set V (Calbiochem) and then centrifuged at $14,000 \mathrm{rpm}$ at $4^{\circ} \mathrm{C}$ for $30 \mathrm{~min}$. The supernatants (soluble fraction) were saved, and the pellets (insoluble fraction) were lysed with buffer (1\% SDS in PBS) containing protease and phosphatase inhibitor cocktail. Each lane was loaded with $20 \mu \mathrm{g}$ of protein. Separated proteins were transferred onto a polyvinylidene fluoride membrane (Bio-Rad), and the membranes were blocked with $5 \%$ nonfat dry milk in Tris-buffered saline and $0.1 \%$ Tween 20. Immunoblots were developed using ECL plus (PerkinElmer). Isolation of nuclear and cytoplasmic fractions was performed by the Nuclear Extract Kit (Active Motif) according to the manufacturer's protocol. Specificity of the nuclear fraction was assessed by SDS-PAGE followed by Western blot analysis with anti-HDAC1 antibody.

For immunohistochemistry, $40-\mu \mathrm{m}$-thick coronal free-floating sections were blocked by 5\% BSA. Biotinylated HRP complex (Vector Laboratories) and 3.3' -diaminobenzidine were used for color development. For image analysis, computer-assisted image analysis program Bioquant Nova Prime, version 6.90 (Carl Zeiss, Germany) was used. Analysis of the in vivo data was confirmed by blinded members of the research team.

Statistical analysis. Data are presented as means \pm SEM and analyzed by one-way ANOVA followed by the Newman-Keuls multiple range test. Significance was determined at $p<0.05$.

\section{Results}

\section{PP2A dephosphorylates pS129 $\alpha$-Syn in a methylation-dependent} manner

To determine the dephosphorylating enzyme, purified human $\alpha$-Syn was incubated in vitro with casein kinase 2 , a major enzyme in brain that phosphorylates serine 129 of $\alpha$-Syn (Ishii et al., 2007). The resulting phosphorylated $\alpha$-Syn was incubated with different concentrations of purified and reconstituted AC dimers of phosphoprotein phosphatase $2 \mathrm{~A}$ or purified phosphoprotein phosphatase 1 . Western blotting of reaction products using p-S129 $\alpha$-Syn antibody indicated marked dephosphorylation by PP2A but not by PP1 (Fig. $1 A, B$ ). The role of PP2A was also confirmed in human dopaminergic neuroblastoma SH-SY5Y cells stably overexpressing $\alpha$-Syn. Incubating these cells with the broad specificity protein phosphatase inhibitor okadaic acid resulted in increased p-S129 $\alpha$-Syn, whereas the PP1-specific inhibitor tautomycetin showed little or no effect (Fig. 1C). In this
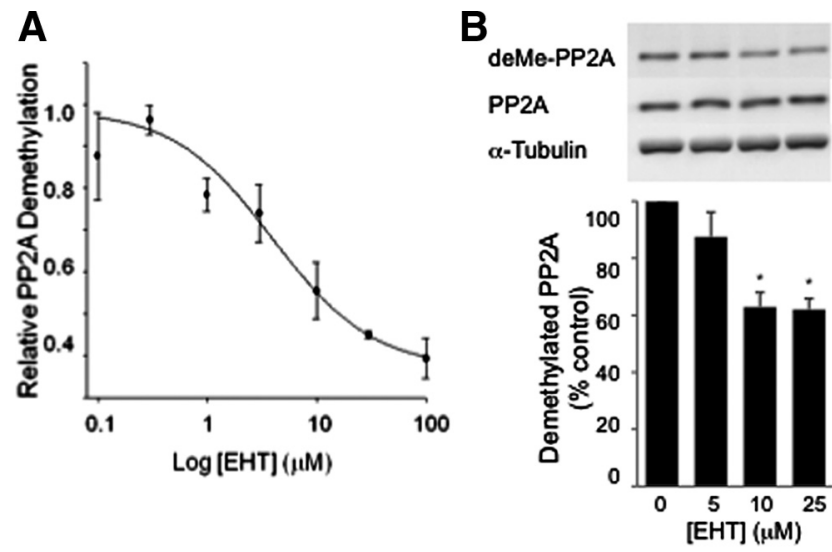

Figure 2. EHT inhibits PP2A demethylation. $\boldsymbol{A}$, In vitro PP2A demethylation is inhibited by EHT. In vitro assay performed with PP2A AC dimers methylated and labeled using PP2A methyl transferase, $S$-[methyl- ${ }^{3} \mathrm{H}$ ]-adenosyl-L-methionine, and incubated with varying concentrations of EHT and $400 \mathrm{~nm}$ PP2A methyl esterase. Amount of ${ }^{3} \mathrm{H}$ remaining in PP2A was assessed using liquid scintillation counting. $\boldsymbol{B}$, EHT inhibits demethylation of PP2A in cultured neurons. Primary hippocampal neurons were incubated with varying concentrations of EHT for $4 \mathrm{~h}$ and harvested for Western blotting. Demethylation of PP2A (deMe-PP2A) was inhibited in a dose-dependent manner by EHT (top and graph, ${ }^{*} p<0.05$ ), while total levels of PP2A (middle) and $\alpha$-tubulin (bottom) were unchanged ( $n=3$ experiments).

cellular system, tautomycetin was able to inhibit PP1 significantly while having no effect on PP2A (Fig. 1D). Okadaic acid has a broad spectrum and can inhibit additional phosphatases at nanomolar (nM) concentrations (Swingle et al., 2007). To confirm the role of PP2A in dephosphorylating $\alpha$-Syn, siRNA to the $\mathrm{C}$ or B $\alpha$ subunits were transfected into $\alpha$-Syn-overexpressing SH-SY5Y cells, and a significant increase in p-S129 $\alpha$-Syn was detected by Western blotting (Fig. $1 E, F$ ). These in vitro and cell-based findings coupled with the high expression of PP2A in the brain (Strack et al., 1997) indicate that PP2A is a major Ser/Thr phosphatase of $\alpha$-Syn.

The impact of PP2A methylation and subunit composition on p-S129 $\alpha$-Syn was investigated next. Phosphorylated human $\alpha$-Syn was incubated with different concentrations of unmethylated or in vitro methylated PP2A AC dimers. Western blotting for p-S129 $\alpha$-Syn showed significantly greater dephosphorylation at a lower concentration of methylated AC dimer compared to the unmethylated form (Fig. 1G,H). In addition to this direct effect on $\mathrm{PP} 2 \mathrm{~A}$ phosphatase activity, the importance of methylating the $\mathrm{C}$ subunit of PP2A in this process was also confirmed and extended with a trimeric form of PP2A. Demethylated-AC or methylated-AC dimers were reconstituted with $\mathrm{B} \alpha$ subunit to yield $\mathrm{AB} \alpha \mathrm{C}$ and Meth- $\mathrm{AB} \alpha \mathrm{C}$ holoenzymes, respectively, and incubated with p-S129 $\alpha$-Syn. The more efficient dephosphorylation of p-S129 $\alpha$-Syn occurred with Meth-AB $\alpha \mathrm{C}$ (Fig. $1 I, J$ ). To further assess the specificity of PP2A activity on p-S129 $\alpha$-Syn, we examined the efficiency of dephosphorylation by alternative heteromeric PP2A assemblies. The trimeric holoenzyme containing $\mathrm{B} \alpha$ subunit $(\mathrm{AB} \alpha \mathrm{C})$ dephosphorylated $\mathrm{p}$-S129 $\alpha$-Syn more efficiently than holoenzymes containing the $\mathrm{B}^{\prime} \alpha\left(\mathrm{AB}^{\prime} \alpha \mathrm{C}\right), \mathrm{B}^{\prime} \gamma 1$ $\left(\mathrm{AB}^{\prime} \gamma 1\right)$ or $\mathrm{B}^{\prime \prime}\left(\mathrm{AB}^{\prime \prime} \mathrm{C}\right)$ isoforms (Fig. $\left.1 K, L\right)$. These results suggest that the methylated $\mathrm{AB} \alpha \mathrm{C} \mathrm{PP} 2 \mathrm{~A}$ isoform is the major phosphatase acting on p-S129 $\alpha$-Syn.

Based on reported aberrations in PP2A in the brains of Alzheimer's disease (AD) patients (Sontag et al., 2004a,b), we sought to build on our findings with $\alpha$-Syn and identify agents that inhibit the demethylation of PP2A as potential therapeutics for $\mathrm{PD}$. In an in vitro screen of natural products, inhibitory activity to demethylation was identified in coffee extracts. Since a negative 
correlation has been observed between coffee consumption and the incidence of both PD and AD (Barranco Quintana et al., 2007; Saaksjarvi et al., 2008), this activity was intriguing for further study. The active agent was purified to homogeneity and identified as eicosanoyl-5-hydroxytryptamide or EHT. Synthetic EHT exhibited the same ability to inhibit PP2A carboxyl demethylation as EHT derived from coffee. EHT inhibits PME-1-mediated demethylation of methylated PP2A under defined conditions with the purified enzymes $\left(\mathrm{IC}_{50}=3.9 \mu \mathrm{M}\right)$ (Fig. 2A). Importantly, EHT was efficacious in cells, inhibiting the demethylation of PP2A in cultured hippocampal neurons (Fig. 2B).

Enhancing PP2A methylation prevents $\alpha$-Syn phosphorylation and aggregation in transgenic mice

As enhancing PP2A methylation increases its activity toward $\alpha$-Syn in vitro (Fig. $1 G-$ $J$ ), we postulated that inhibiting the demethylation of PP2A could increase its activity and reduce levels of phosphorylated $\alpha$-Syn in vivo, leading to decreased protein aggregation and neuroprotection.

Pharmacokinetic studies delivering $\left[{ }^{3} \mathrm{H}\right]$-EHT intraperitoneally revealed that the compound is able to cross the bloodbrain barrier achieving micromolar $(\mu \mathrm{M})$ levels of ${ }^{3} \mathrm{H}$-label, sufficient to inhibit PP2A demethylation and indicating its feasibility for systemic administration. Male mouse pups transgenic for human $\alpha$-Syn $\left(\alpha-\right.$ Syn $\left.^{\text {Tg }}\right)$ under the control of the Thy-1 promoter (Rockenstein et al., 2002) and wild-type littermates were placed upon weaning on a diet containing two different concentrations of EHT $(0.01 \%$ and $0.1 \%$ ) or control feed, and chow consumption was measured weekly. Given ad libitum access to feed, these EHT concentrations translate to $12 \mathrm{mg} / \mathrm{kg} / \mathrm{d}$ and $120 \mathrm{mg} /$ $\mathrm{kg} / \mathrm{d}$, respectively. Motor behavior was tested every 3 months, and animals were euthanized at 9 months for biochemical and immunohistochemical studies.

Consistent with the pharmacological action of EHT in cultured hippocampal neurons, Western blotting of cortical tissue lysates showed that the percentage of demethylated $\mathrm{PP} 2 \mathrm{~A}$ relative to total $\mathrm{PP} 2 \mathrm{~A}$ expression decreased by $76 \%$ in EHT-treated wild-type mice and by $58 \%$ in $\alpha$-Syn ${ }^{\mathrm{Tg}}$ mice compared with their respective control chow-fed littermates (Fig. $3 A-D$ ). As total PP2A expression was not affected by this treatment, the decline in the levels of demethylated enzyme indicates a dramatic decrease in the rate of PME-1 demethylation activity toward PP2A. This was associated with a significant $45 \%$ decline in the amount of p-Ser129- $\alpha$-Syn in the insoluble fraction of brain lysates from animals fed with $0.1 \%$ of the compound (Fig. $3 B, E$ ). A dose-dependent decrease in high-molecular weight insoluble $\alpha$-Syn aggregation by West-
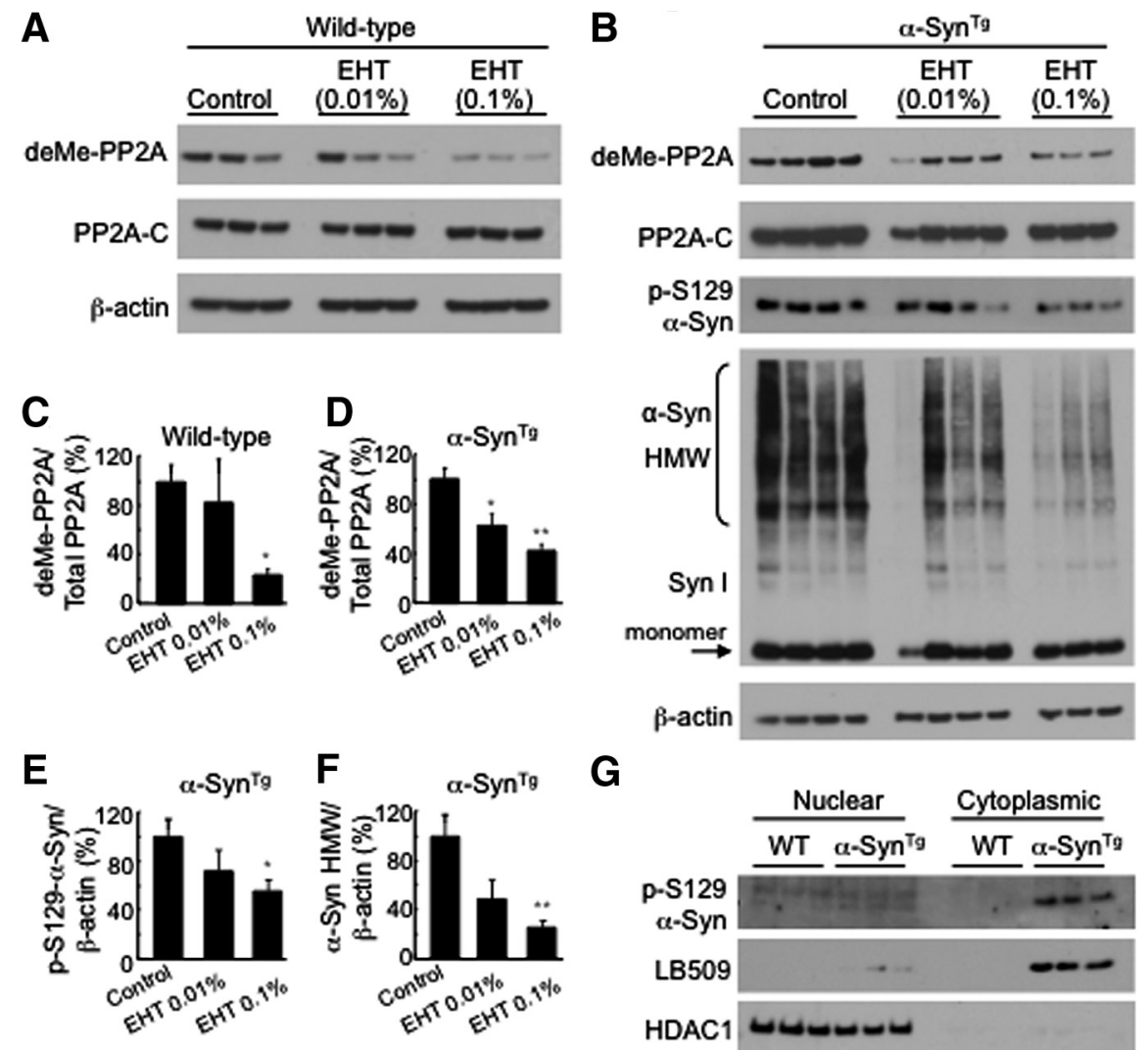

G
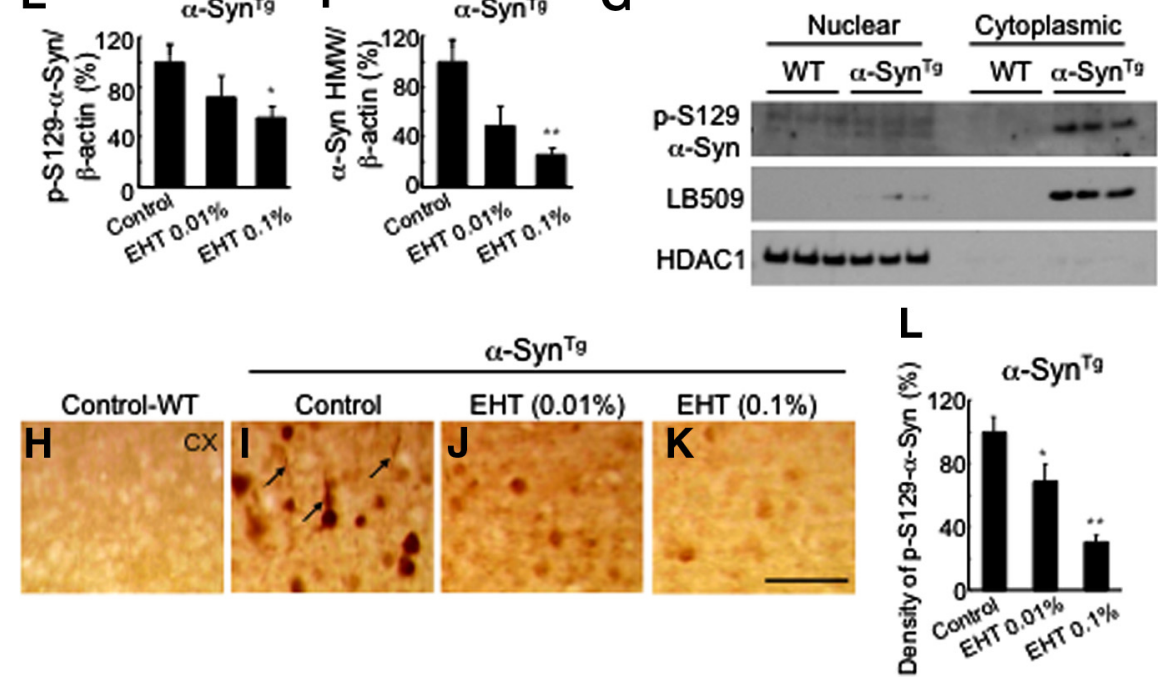

Figure 3. EHT administration modulates PP2A methylation and prevents $\alpha$-Syn phosphorylation and aggregation in transgenic mice. $\boldsymbol{A}$, Western blots of cortical tissue lysates from wild-type mice. RIPA insoluble fraction was solubilized with $1 \%$ SDS and probed with antibodies to demethylated PP2A (deMe-PP2A) and total PP2A-C subunit. B, Western blots for PP2A as in Figure $2 A$ with lysates from $\alpha$-Syn ${ }^{\text {Tg }}$ mice. These samples were also probed with phospho-S129- $\alpha$-Syn antibody and total $\alpha$-Syn antibody (Syn 1) showing reduction of high molecular weight aggregation. C, Quantification of band intensities in Figure $2 A$ showing significant reduction with $0.1 \%$ EHT administration ( $n=3$ for each bar). $\boldsymbol{D}-\boldsymbol{F}$, Quantification of band intensities in Figure $2 B$ showing significant decrease in demethylated PP2A, phospho-S129- $\alpha$-Syn, and aggregated $\alpha$-Syn ( $n$ for control feed $=4$; low dose $=4$; high dose $=3$ ). G, Western blots of fractionated brain lysates with phospho-S129- $\alpha$-Syn antibody and LB509 (human monoclonal $\alpha$-Syn antibody) show the phosphorylated transgene expressed primarily in the cytoplasmic fraction, while the nuclear marker HDAC1 is in the nuclear fraction. WT, Wild type. $\boldsymbol{H}-\boldsymbol{K}$, Immunohistochemistry with phospho-S129- $\alpha$-Syn antibody of cortical tissue from $\alpha$-Syn ${ }^{\top \mathrm{Tg}}$ mice treated with control, $0.01 \% \mathrm{EHT}$, and $0.1 \%$ EHT, respectively, demonstrating significant decrease in the number of immunoreactiveneurons and neurites (arrows). Scale bar, 100 $\mu \mathrm{m} . L$, Quantification of the number of cortical phospho-S129- $\alpha$-Syn-immunoreactive neurons (control feed, $n=6$; low dose, $n=5$; high dose, $n=4) .{ }^{*} p<0.05,{ }^{* *} p<0.001$.

ern blotting was also seen with EHT treatment compared to controls (Fig. $3 B, F$ ), while levels of monomeric $\alpha$-Syn exhibited no significant alterations (Fig. $3 B$ ). Subcellular fractionation of brain lysates performed to isolate nuclear and cytoplasmic compartments indicated that p-Ser129- $\alpha$-Syn is localized primarily in the cytoplasm (Fig. $3 G$ ).

Immunohistochemical analysis confirmed the effects of EHT administration on $\mathrm{p}-\alpha$-Syn accumulation (Fig. $3 H-L$ ). The number of p-Ser129- $\alpha$-Syn-immunoreactive neurons in the cortex of EHTtreated $\alpha$-Syn ${ }^{\mathrm{Tg}}$ mice decreased dramatically in a dose-dependent 

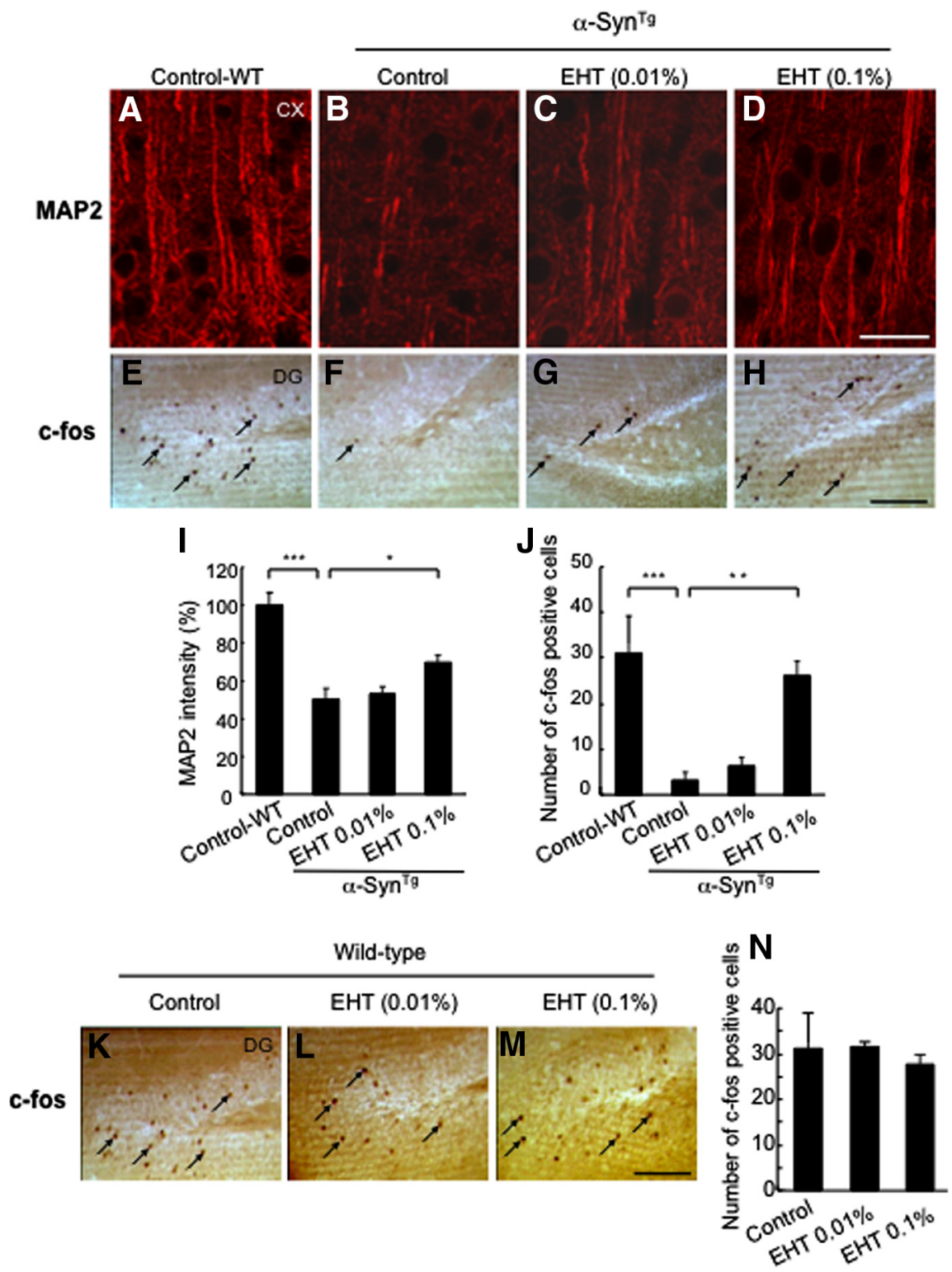

Figure 4. Improved dendritic arborization and neuronal activity by EHT. $A-D$, Confocal micrographs of cortical sections stained with MAP2. Scale bar, $25 \mu \mathrm{m}$. WT, Wild type. $\boldsymbol{E}-\boldsymbol{H}$, c-fos-immunoreactive neurons in the hippocampus. Arrows point to some of the c-fospositive neurons. Scale bar, $100 \mu \mathrm{m}$. I, Quantification of MAP2-immunoreactive dendrites by ImageJ ( $n$ for each of the four groups $=5$ ). ${ }^{*} p<0.05,{ }^{* * *} p<0.001$.J, Quantification of c-fos-positive neurons in the dentate gyrus (control fed wild-type mice, $n=4$; control fed $\alpha$-Syn ${ }^{\mathrm{Tg}}{ }^{,} n=6$; low dose $\alpha$-Syn ${ }^{\mathrm{Tg}}, n=4$; high dose $\alpha$-Syn $\left.{ }^{\mathrm{Tg}}, n=4\right){ }^{* *} p<0.01,{ }^{* * *} p<0.001 . \mathrm{K}-\mathbf{N}$, c-fos-immunoreactive neurons in the dentate gyrus of the hippocampus in wild-type mice. Arrows point to some of the $c$-fos-positive neurons. No difference was found with EHT administration (control fed, $n=4$; low dose, $n=3$; high dose, $n=3$ ). Scale bar, $100 \mu \mathrm{m}$.

manner, with a $31 \%$ decrease in low dose-treated animals and $70 \%$ in the high-dose group (Fig. $3 L$ ). Similarly, a substantial decrease in p-Ser129- $\alpha$-Syn-immunoreactive neurites was also noted in the cortex of EHT-treated mice (Fig. $3 I-K$ ).

\section{Improved neuronal activity and dendritic arborization by EHT treatment}

The neuropathological impact of $\alpha$-Syn overexpression and the effect of chronic EHT treatment were addressed next. $\alpha$-Syn ${ }^{\text {Tg }}$ mice have substantial depletion of the cytoskeletal microtubule associated protein 2, MAP2, in the cortex (Fig. 4A, $B, I$ ), which is indicative of reduced dendritic complexity (Harada et al., 2002). However, animals treated with EHT demonstrated a noticeable, dose-dependent, increase in MAP2-immunoreactive neurites
(Fig. $4 C, D, I$ ). In addition, a marked depletion of the number of neurons immunoreactive to the immediate early gene product c-Fos (Palop et al., 2003), which is a surrogate marker for neuronal activity, was noted in the dentate gyrus of the hippocampi of $\alpha$-Syn ${ }^{\text {Tg }}$ mice compared to wild-type animals (Fig. $4 E, F, J$ ). This was prevented in EHT-treated animals (Fig. $4 G, H, J$ ). EHT did not impact the number of c-fos-immunoreactive neurons in wild-type mice (Fig. $4 K-N$ ). The $\alpha$-Syn ${ }^{\text {Tg }}$ mice used in these studies do not demonstrate degeneration of nigral dopaminergic neurons by 9 months of age. They also do not have appreciable deficits in striatal nerve terminal integrity assessed by synaptophysin immunohistochemistry, nor do they have significant depletion of striatal catecholamines or tyrosine hydroxylase content.

\section{Repression of astrocytic and microglial} activation by EHT treatment

Histopathological studies of non-neuronal cells also revealed significant changes with $\alpha$-Syn overexpression and EHT treatment. $\alpha$-Syn ${ }^{\mathrm{Tg}}$ mice given control feed demonstrated marked astroglial activation as detected by increased numbers of GFAPimmunoreactive cells in cerebral cortex and hippocampus (Fig. 5A, B,E,F). EHT treatment resulted in the presence of fewer GFAP-positive cells (Fig. 5C,D, G,H). These changes in astrocytic cells with transgenic $\alpha$-Syn expression and EHT treatment paralleled the profile of GFAP expression observed by Western blotting (Fig. 5M,N). A similar trend of microglial proliferation was noted in the cortex of untreated transgenic mice and diminished by EHT administration (Fig. 5I-L). Consistent with the latter finding, Western blot analysis showed that the expression of iNOS in the cortex of untreated transgenic mice was significantly greater than that in wild-type littermates but decreased with EHT treatment (Fig. $5 \mathrm{M}, \mathrm{O})$. Notably, this treatment had no effect on GFAP or iNOS expression in wildtype animals (Fig. 5M-O). These findings collectively point to a significant astroglial and microglial activation by transgenic overexpression of human $\alpha$-Syn and the diminution of this reactive process by EHT.

\section{Improved behavioral outcome of $\alpha-S y n^{\mathrm{Tg}}$ mice with EHT treatment}

Sensorimotor behavior assessments showed significant improvement in transgenic mice raised on EHT-containing diet. Rotarod performance, which is markedly impaired in transgenic mice compared to wild-type littermates on control feed, was significantly improved with $0.1 \%$ EHT at 3 months (Fig. $6 A$ ) and 6 months of age (Fig. $6 B$ ). Nesting behavior, which requires shredding cotton from a tightly packed square, was also markedly impaired in $\alpha$-Syn ${ }^{\mathrm{Tg}}$ mice 
at 9 months but was significantly improved in EHT-treated animals (Fig. 6C). Although nesting behavior has been used to assess nigrostriatal sensorimotor function in rodents (Szczypka et al., 2001; Deacon, 2006), the $\alpha$-Syn ${ }^{\mathrm{Tg}}$ mice used in the present study are significantly impaired with respect to this complex behavior, as has been described previously (Fleming et al., 2004), despite lack of appreciable dopaminergic deficits by 9 months of age. This behavioral impairment has been attributed to a decline in fine motor skills or reduction in the shredding urge (Fleming et al., 2004), perhaps due to cortical dysfunction related to high levels of $\alpha$-Syn expression (Kolb and Whishaw, 1985; Rockenstein et al., 2002).

\section{Discussion}

The findings presented here demonstrate that PP2A catalyzes the dephosphorylation of phospho-Ser129 $\alpha$-Syn and that the methylation state of the PP2A C subunit regulates this activity. Furthermore, enhancement of PP2A methylation is beneficial in reducing $\alpha$-Syn phosphorylation and aggregation, preventing neuropathological features associated with $\alpha$-Syn and improving behavioral outcome in $\alpha$-Syn transgenic mice. Interplay between $\alpha$-Syn and PP2A in regulating tyrosine hydroxylase activity in dopaminergic neurons has previously been described (Saraf et al., 2007; Lou et al., 2010). The results reported here suggest that PP2A acts as an upstream regulator of $\alpha$-Syn phosphorylation so that agents that enhance PP2A phosphatase activity toward phospho-Ser129 $\alpha$-Syn may provide therapeutic benefits.

Our results also support a significant role of $\alpha$-Syn phosphorylation at serine 129 in neuronal dysfunction in vivo. Prior studies concerning the role of this phosphorylation using genetic or viral vector-mediated delivery of Ser129Asp or Ser129Ala $\alpha$-Syn mutants in rodent and Drosophila models have yielded inconsistent results (Chen and Feany, 2005; Gorbatyuk et al., 2008; Azeredo da Silveira et al., 2009; McFarland et al., 2009). Although designed as a phosphomimetic, in vitro biophysical studies indicate that S129D does not faithfully reproduce the effects of native phosphorylation (Paleologou et al., 2008). On the other hand, our present observations are based on pharmacological manipulation of the native phosphorylation state of $\alpha$-Syn in the brain.

The mechanism(s) of the protective effects of EHT downstream of $\alpha$-Syn in this mouse model of $\alpha$-synucleinopathy deserve additional consideration. The marked depletion of c-fos-immunoreactive neurons in
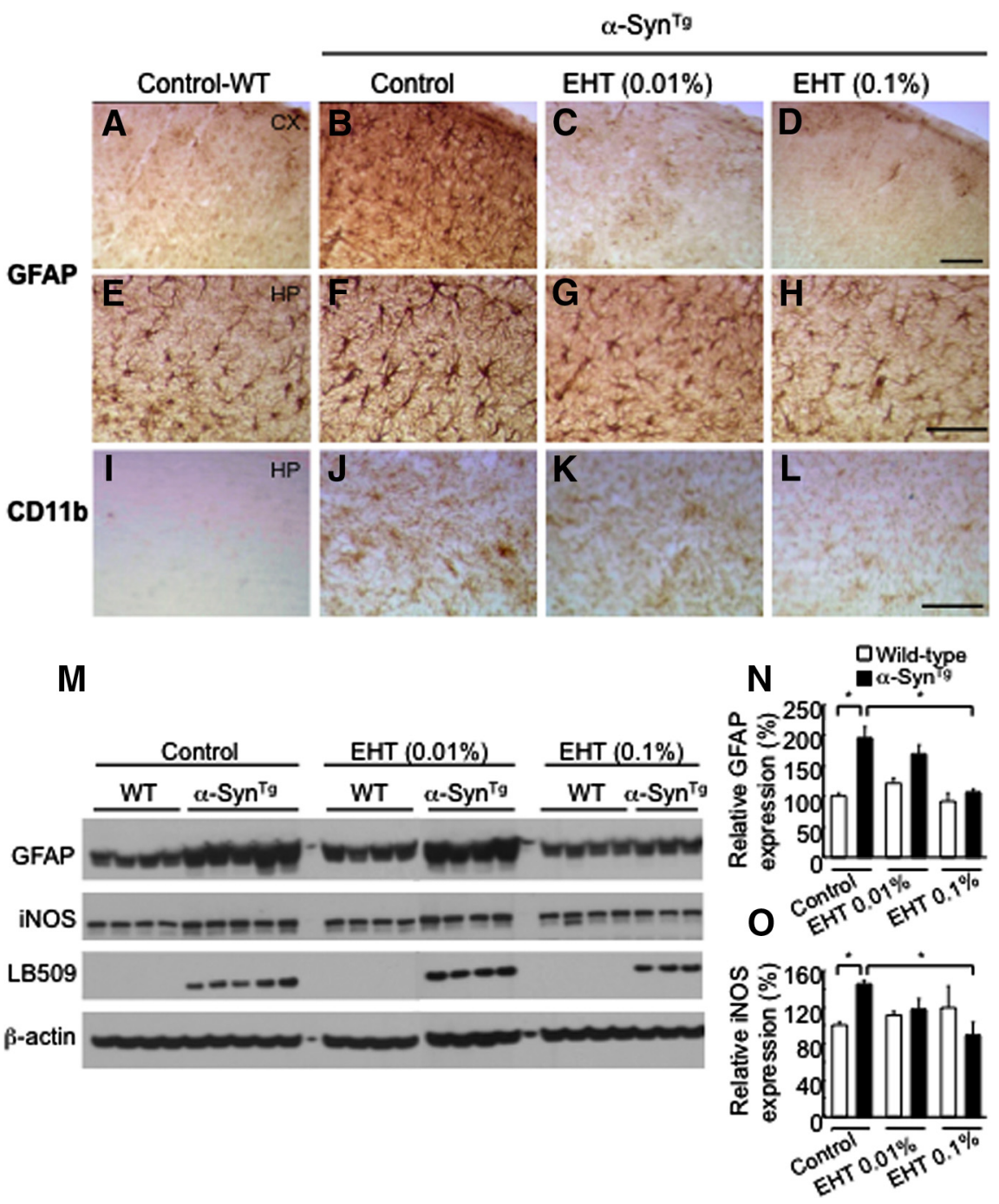

Figure 5. Repression of glial activation by EHT administration. $\boldsymbol{A}-\boldsymbol{H}$, Immunohistochemistry for GFAP in cortex (top) and hippocampus (middle) demonstrating significantly more intense staining in $\alpha$-Syn ${ }^{T g}$ mice compared to wild-type littermates and reduction with EHT treatment. Scale bar, $100 \mu \mathrm{m}$. $\boldsymbol{I}-\boldsymbol{L}$, Staining with the microglial marker CD11b showing the same trend. $\boldsymbol{M}$, Western blotting of cortical tissue lysates (soluble fraction) with GFAP, iNOS, and LB509 (human monoclonal $\alpha$-Syn antibody). $N$, Quantification of GFAP band intensities relative to $\beta$-actin shown in $\boldsymbol{M}$. O, Quantification of iNOS band intensities shown in $M$. ${ }^{*} p<0.05$.
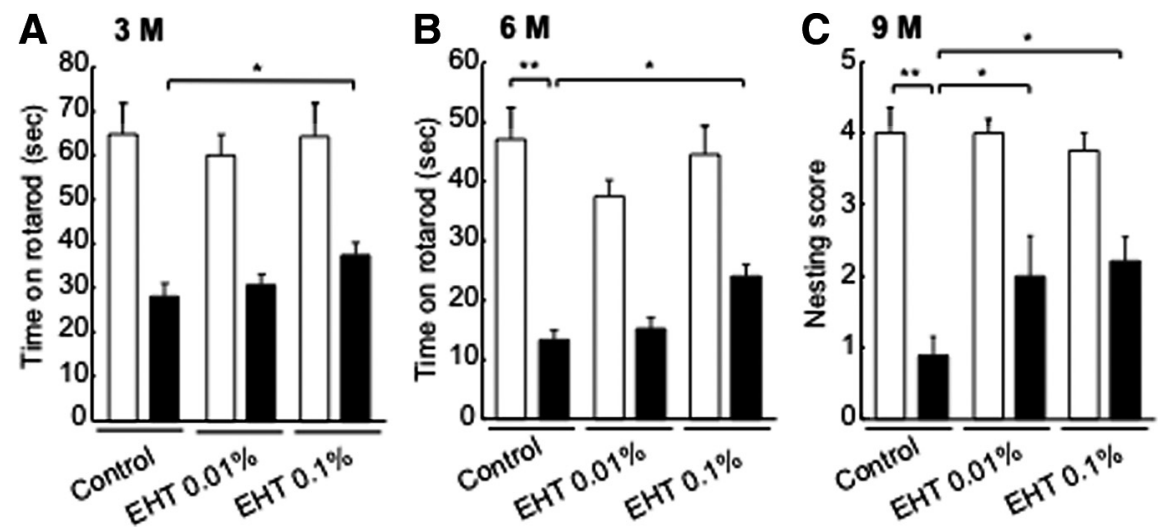

Figure 6. Amelioration of $\alpha$-Syn-mediated behavioral deficits by EHT administration. $A$, Performance on the rotarod at 3 months of age (control fed wild-type mice, $n=9$; control fed $\alpha$-Syn ${ }^{\top 9}, n=12$; low dose wild-type, $n=10$; low dose $\alpha$-Syn ${ }^{\top 9}, n=13$; high dose wild-type, $n=9$; high dose $\alpha$-Syn ${ }^{\top \mathrm{Tg}}, n=12$ ). $\boldsymbol{B}$, Performance on the rotarod at 6 months. (control fed wild-type mice, $n=9$; control fed $\alpha$-Syn ${ }^{\mathrm{T}}, n=12$; low dose wild-type, $n=10$; low dose $\alpha$-Syn ${ }^{\mathrm{Tg}}, n=11$; high dose wild-type, $n=9$; high dose $\alpha$-Syn $\left.{ }^{\mathrm{T}}, n=10\right)$. C, Nesting behavior scored at 9 months (control fed wild-type mice, $n=4$; control fed $\alpha$-Syn ${ }^{\mathrm{Tg}}, n=4$; low dose wild-type, $n=4$; low dose $\alpha$-Syn ${ }^{\mathrm{Tg}}, n=6$; high dose wild-type, $n=6$; high dose $\alpha$-Syn $\left.{ }^{\mathrm{Tg}}, n=5\right) .{ }^{*} p<0.05$; ${ }^{* *} p<0.01$. 
the hippocampus of $\alpha$-Syn ${ }^{\mathrm{Tg}}$ mice indicates severely impaired neuronal activity as a result of $\alpha$-Syn overexpression. The substantial improvement of this marker with EHT treatment suggests protection either directly through dephosphorylation of p-Ser129 $\alpha$-Syn or indirectly through some off-target effect of EHT that may or may not be related to increased PP2A activity. The fact that EHT did not impact c-fos-immunoreactive neurons in wild-type mice supports the notion that this protective effect is directly associated with the modulation of $\alpha$-Syn phosphorylation. Preservation of MAP2positive dendritic arborizations implies improved neuronal integrity. This could also be related to maintenance of microtubule networks through decreased phosphorylation of tau, another target of the $\mathrm{AB} \alpha \mathrm{C}$ neuronal variant of PP2A (Liu et al., 2005). Molecular, genetic, and neuropathological observations point to an association between $\alpha$-Syn and tau, and phosphorylated tau inclusions have been detected in another $\alpha$-Syn transgenic mouse line (Frasier et al., 2005). Whether the effects of EHT on $\alpha$-Syn or tau predominate in explaining the results seen in the present study has not been definitively proven, although tau phosphorylation appears to be downstream of $\alpha$-Syn (Frasier et al., 2005; Khandelwal et al., 2010). Since the mice used in this study do not have demonstrable synaptic terminal deficits by 9 months of age as determined by synaptophysin immunoreactivity, protecting these terminals anatomically is an unlikely mechanism. However, it is still possible that synaptic transmitter release is impaired in these mice, as has been suggested in other murine models (Abeliovich et al., 2000; Yavich et al., 2004), and that EHT treatment could have prevented this impairment. It is unlikely that the effects we have observed are achieved through modulating phosphorylation of multiple PP2A substrates, as methylation only strongly affects the assembly of $\mathrm{B} \alpha$-containing PP2A holoenzymes (Longin et al., 2007). Therefore, the effects of EHT, through modulating PP2A methylation, could only influence the demonstrated substrates of this isoform, namely $\alpha$-Syn (the present study), tau (Liu et al., 2005), $\beta$-catenin (Zhang et al., 2009), and Raf (Kao et al., 2004). The strong correlation between our dose-dependent effects on PP2A methylation and $\alpha$-Syn dephosphorylation makes this the most obvious pathway, although others cannot be completely discounted.

Our data point to an additional mechanism for the protective activity of EHT through inhibition of microglial/astroglial activation and iNOS expression. Neuroinflammation is a key component of PD (Tansey and Goldberg, 2010) and can influence $\alpha$-Syn aggregation (Gao et al., 2008). Although $\alpha$-Syn-mediated microglial activation has been reported in mouse models of $\alpha$-Syn overexpression (Su et al., 2008; Theodore et al., 2008), it is unknown whether S129 phosphorylated $\alpha$-Syn is a stronger trigger of this reactive process than unphosphorylated $\alpha$-Syn. Additionally, EHT could have a direct anti-inflammatory effect through activation of PP2A (Shanley et al., 2001). This would be responsible for reduced glial activation independent of its actions on $\alpha$-Syn phosphorylation.

Modulation of PP2A provides a novel approach for treating PD and other $\alpha$-synucleinopathies. Interestingly, the active compound in these studies, eicosanoyl-5-hydroxytryptamide, was identified as the major PP2A demethylation inhibitor in coffee. A number of epidemiological studies have suggested that consumption of this beverage is associated with a reduced risk of developing PD (Hellenbrand et al., 1996; Fall et al., 1999; Benedetti et al., 2000). Some of these studies have suggested caffeine to be the active ingredient in this inverse association (Ross et al., 2000; Ascherio et al., 2001), and the inhibitory effect of caffeine on adenosine $\mathrm{A} 2 \mathrm{~A}$ receptors is implicated in preclinical studies to protect dopaminergic neurons against toxins such as MPTP (1-methyl-4-phenyl-1,2,3,6-tetrahydropyridine) (Chen et al., 2001). The present observations provide an additional active agent in coffee that appears to exert beneficial pharmacological effects in the brain through $\alpha$-Syn. Appreciable levels of EHT and closely related $\mathrm{N}$-alkanoyl-5-hydoxytryptamides are present in coffee, averaging $0.5 \mathrm{mg} / \mathrm{g}$ (Lang and Hofmann, 2005), suggesting that human exposure to EHT through coffee consumption may be a contributing factor to the putative beneficial effect of this beverage in reducing PD risk.

Together, the above in vitro and in vivo findings suggest that targeting PP2A is a promising therapeutic strategy to mitigate the neuropathology of $\alpha$-synucleinopathies. This approach appears particularly effective considering the fact that multiple kinases phosphorylate $\alpha$-Syn at serine 129 (Pronin et al., 2000; Anderson et al., 2006; Inglis et al., 2009; Mbefo et al., 2010) and, therefore, inhibiting a single kinase is unlikely to impact significantly the extent of this post-translational modification. Recent studies with sodium selenate, a PP2A enhancer, have demonstrated that such an approach may also be relevant in reducing tau hyperphosphorylation in aged mice and in transgenic tauopathy models of AD (Corcoran et al., 2010; van Eersel et al., 2010). PP2A modulation may, therefore, provide a common strategy for treating neurodegenerative proteinopathies associated with hyperphosphorylated pathogenic proteins (Hanger et al., 2009).

\section{References}

Abeliovich A, Schmitz Y, Fariñas I, Choi-Lundberg D, Ho WH, Castillo PE, Shinsky N, Verdugo JM, Armanini M, Ryan A, Hynes M, Phillips H, Sulzer D, Rosenthal A (2000) Mice lacking alpha-synuclein display functional deficits in the nigrostriatal dopamine system. Neuron 25:239-252.

Anderson JP, Walker DE, Goldstein JM, de Laat R, Banducci K, Caccavello RJ, Barbour R, Huang J, Kling K, Lee M, Diep L, Keim PS, Shen X, Chataway T, Schlossmacher MG, Seubert P, Schenk D, Sinha S, Gai WP, Chilcote TJ (2006) Phosphorylation of Ser-129 is the dominant pathological modification of $\alpha$-synuclein in familial and sporadic Lewy body disease. J Biol Chem 281:29739-29752.

Ascherio A, Zhang SM, Hernán MA, Kawachi I, Colditz GA, Speizer FE, Willett WC (2001) Prospective study of caffeine consumption and risk of Parkinson's disease in men and women. Ann Neurol 50:56-63.

Azeredo da Silveira S, Schneider BL, Cifuentes-Diaz C, Sage D, Abbas-Terki T, Iwatsubo T, Unser M, Aebischer P (2009) Phosphorylation does not prompt, nor prevent, the formation of alpha-synuclein toxic species in a rat model of Parkinson's disease. Hum Mol Genet 18:872-887.

Barranco Quintana JL, Allam MF, Serrano Del Castillo A, Fernández-Crehuet Navajas R (2007) Alzheimer's disease and coffee: a quantitative review. Neurol Res 29:91-95.

Benedetti MD, Bower JH, Maraganore DM, McDonnell SK, Peterson BJ, Ahlskog JE, Schaid DJ, Rocca WA (2000) Smoking, alcohol, and coffee consumption preceding Parkinson's disease: a case-control study. Neurology 55:1350-1358.

Bryant JC, Westphal RS, Wadzinski BE (1999) Methylated C-terminal leucine residue of PP2A catalytic subunit is important for binding of regulatory $\beta$ alpha subunit. Biochem J 339:241-246.

Chen JF, Xu K, Petzer JP, Staal R, Xu YH, Beilstein M, Sonsalla PK, Castagnoli K, Castagnoli N Jr, Schwarzschild MA (2001) Neuroprotection by caffeine and $\mathrm{A}(2 \mathrm{~A})$ adenosine receptor inactivation in a model of Parkinson's disease. J Neurosci 21:RC143.

Chen L, Feany MB (2005) Alpha-synuclein phosphorylation controls neurotoxicity and inclusion formation in a Drosophila model of Parkinson disease. Nat Neurosci 8:657-663.

Corcoran NM, Martin D, Hutter-Paier B, Windisch M, Nguyen T, Nheu L, Sundstrom LE, Costello AJ, Hovens CM (2010) Sodium selenate specifically activates PP2A phosphatase, dephosphorylates tau and reverses memory deficits in an Alzheimer's disease model. J Clin Neurosci 17:1025-1033.

Deacon RM (2006) Assessing nest building in mice. Nat Protoc 1:1117-1119. Fall PA, Fredrikson M, Axelson O, Granérus AK (1999) Nutritional and 
occupational factors influencing the risk of Parkinson's disease: a casecontrol study in southeastern Sweden. Mov Disord 14:28-37.

Fleming SM, Salcedo J, Fernagut PO, Rockenstein E, Masliah E, Levine MS, Chesselet MF (2004) Early and progressive sensorimotor anomalies in mice overexpressing wild-type human alpha-synuclein. J Neurosci 24:9434-9440.

Frasier M, Walzer M, McCarthy L, Magnuson D, Lee JM, Haas C, Kahle P, Wolozin B (2005) Tau phosphorylation increases in symptomatic mice overexpressing A30P alpha-synuclein. Exp Neurol 192:274-287.

Fujiwara H, Hasegawa M, Dohmae N, Kawashima A, Masliah E, Goldberg MS, Shen J, Takio K, Iwatsubo T (2002) $\alpha$-Synuclein is phosphorylated in synucleinopathy lesions. Nat Cell Biol 4:160-164.

Gao HM, Kotzbauer PT, Uryu K, Leight S, Trojanowski JQ, Lee VM (2008) Neuroinflammation and oxidation/nitration of $\alpha$-synuclein linked to dopaminergic neurodegeneration. J Neurosci 28:7687-7698.

Goedert M (2001) Alpha-synuclein and neurodegenerative diseases. Nat Rev Neurosci 2:492-501.

Gorbatyuk OS, Li S, Sullivan LF, Chen W, Kondrikova G, Manfredsson FP, Mandel RJ, Muzyczka N (2008) The phosphorylation state of Ser-129 in human alpha-synuclein determines neurodegeneration in a rat model of Parkinson disease. Proc Natl Acad Sci U S A 105:763-768.

Hanger DP, Anderton BH, Noble W (2009) Tau phosphorylation: the therapeutic challenge for neurodegenerative disease. Trends Mol Med 15:112-119.

Harada A, Teng J, Takei Y, Oguchi K, Hirokawa N (2002) MAP2 is required for dendrite elongation, PKA anchoring in dendrites, and proper PKA signal transduction. J Cell Biol 158:541-549.

Hellenbrand W, Boeing H, Robra BP, Seidler A, Vieregge P, Nischan P, Joerg J, Oertel WH, Schneider E, Ulm G (1996) Diet and Parkinson's disease. II: A possible role for the past intake of specific nutrients. Results from a self-administered food-frequency questionnaire in a case-control study. Neurology 47:644-650.

Inglis KJ, Chereau D, Brigham EF, Chiou SS, Schöbel S, Frigon NL, Yu M, Caccavello RJ, Nelson S, Motter R, Wright S, Chian D, Santiago P, Soriano F, Ramos C, Powell K, Goldstein JM, Babcock M, Yednock T, Bard F, et al. (2009) Polo-like kinase 2 (PLK2) phosphorylates alpha-synuclein at serine 129 in central nervous system. J Biol Chem 284:2598-2602.

Ishii A, Nonaka T, Taniguchi S, Saito T, Arai T, Mann D, Iwatsubo T, Hisanaga S, Goedert M, Hasegawa M (2007) Casein kinase 2 is the major enzyme in brain that phosphorylates Ser129 of human alpha-synuclein: implication for alpha-synucleinopathies. FEBS Lett 581:4711-4717.

Kanda S, Bishop JF, Eglitis MA, Yang Y, Mouradian MM (2000) Enhanced vulnerability to oxidative stress by alpha-synuclein mutations and C-terminal truncation. Neuroscience 97:279-284.

Kao G, Tuck S, Baillie D, Sundaram MV (2004) C. elegans SUR-6/PR55 cooperates with LET-92/protein phosphatase $2 \mathrm{~A}$ and promotes Raf activity independently of inhibitory Akt phosphorylation sites. Development 131:755-765.

Khandelwal PJ, Dumanis SB, Feng LR, Maguire-Zeiss K, Rebeck G, Lashuel HA, Moussa CE (2010) Parkinson-related parkin reduces $\alpha$-Synuclein phosphorylation in a gene transfer model. Mol Neurodegener 5:47.

Kolb B, Whishaw IQ (1985) Neonatal frontal lesions in hamsters impair species-typical behaviors and reduce brain weight and neocortical thickness. Behav Neurosci 99:691-706.

Lang R, Hofmann T (2005) A versatile method for the quantitative determination of $\beta$-N-alkanoyl-5-hydroxytryptamides in roasted coffee. Eur Food Res Technol 220:638-643.

Lee J, Stock J (1993) Protein phosphatase 2A catalytic subunit is methylesterified at its carboxyl terminus by a novel methyltransferase. J Biol Chem 268:19192-19195.

Lee J, Chen Y, Tolstykh T, Stock J (1996) A specific protein carboxyl methylesterase that demethylates phosphoprotein phosphatase $2 \mathrm{~A}$ in bovine brain. Proc Natl Acad Sci U S A 93:6043-6047.

Liu F, Grundke-Iqbal I, Iqbal K, Gong CX (2005) Contributions of protein phosphatases PP1, PP2A, PP2B and PP5 to the regulation of tau phosphorylation. Eur J Neurosci 22:1942-1950.

Longin S, Zwaenepoel K, Louis JV, Dilworth S, Goris J, Janssens V (2007) Selection of protein phosphatase $2 \mathrm{~A}$ regulatory subunits is mediated by the C terminus of the catalytic Subunit. J Biol Chem 282:26971-26980.

Lou H, Montoya SE, Alerte TN, Wang J, Wu J, Peng X, Hong CS, Friedrich EE, Mader SA, Pedersen CJ, Marcus BS, McCormack AL, Di Monte DA, Daubner SC, Perez RG (2010) Serine 129 phosphorylation reduces \{alpha\}-synuclein's ability to regulate tyrosine hydroxylase and protein phosphatase 2A in vitro and in vivo. J Biol Chem 285:17648-17661.

Mbefo MK, Paleologou KE, Boucharaba A, Oueslati A, Schell H, Fournier M, Olschewski D, Yin G, Zweckstetter M, Masliah E, Kahle PJ, Hirling H, Lashuel HA (2010) Phosphorylation of synucleins by members of the Polo-like kinase family. J Biol Chem 285:2807-2822.

McFarland NR, Fan Z, Xu K, Schwarzschild MA, Feany MB, Hyman BT, McLean PJ (2009) Alpha-synuclein S129 phosphorylation mutants do not alter nigrostriatal toxicity in a rat model of Parkinson disease. J Neuropathol Exp Neurol 68:515-524.

Neumann M, Kahle PJ, Giasson BI, Ozmen L, Borroni E, Spooren W, Müller V, Odoy S, Fujiwara H, Hasegawa M, Iwatsubo T, Trojanowski JQ, Kretzschmar HA, Haass C (2002) Misfolded proteinase K-resistant hyperphosphorylated alpha-synuclein in aged transgenic mice with locomotor deterioration and in human alpha-synucleinopathies. J Clin Invest 110:1429-1439.

Ogris E, Du X, Nelson KC, Mak EK, Yu XX, Lane WS, Pallas DC (1999) A protein phosphatase methylesterase (PME-1) is one of several novel proteins stably associating with two inactive mutants of protein phosphatase 2A. J Biol Chem 274:14382-14391.

Paleologou KE, Schmid AW, Rospigliosi CC, Kim HY, Lamberto GR, Fredenburg RA, Lansbury PT Jr, Fernandez CO, Eliezer D, Zweckstetter M, Lashuel HA (2008) Phosphorylation at Ser-129 but not the phosphomimics S129E/D inhibits the fibrillation of $\alpha$-Synuclein. J Biol Chem 283:16895-16905.

Palop JJ, Jones B, Kekonius L, Chin J, Yu GQ, Raber J, Masliah E, Mucke L (2003) Neuronal depletion of calcium-dependent proteins in the dentate gyrus is tightly linked to Alzheimer's disease-related cognitive deficits. Proc Natl Acad Sci U S A 100:9572-9577.

Pronin AN, Morris AJ, Surguchov A, Benovic JL (2000) Synucleins are a novel class of substrates for $\mathrm{G}$ protein-coupled receptor kinases. J Biol Chem 275:26515-26522.

Rockenstein E, Mallory M, Hashimoto M, Song D, Shults CW, Lang I, Masliah E (2002) Differential neuropathological alterations in transgenic mice expressing alpha-synuclein from the platelet-derived growth factor and Thy-1 promoters. J Neurosci Res 68:568-578.

Ross GW, Abbott RD, Petrovitch H, Morens DM, Grandinetti A, Tung KH, Tanner CM, Masaki KH, Blanchette PL, Curb JD, Popper JS, White LR (2000) Association of coffee and caffeine intake with the risk of Parkinson disease. JAMA 283:2674-2679.

Sääksjärvi K, Knekt P, Rissanen H, Laaksonen MA, Reunanen A, Männistö S (2008) Prospective study of coffee consumption and risk of Parkinson's disease. Eur J Clin Nutr 62:908-915.

Sager TN, Kirchhoff J, Mørk A, Van Beek J, Thirstrup K, Didriksen M, Lauridsen JB (2010) Nest building performance following MPTP toxicity in mice. Behav Brain Res 208:444-449.

Saraf A, Virshup DM, Strack S (2007) Differential expression of the B' $\beta$ regulatory subunit of protein phosphatase $2 \mathrm{~A}$ modulates tyrosine hydroxylase phosphorylation and catecholamine synthesis. J Biol Chem 282:573-580.

Shanley TP, Vasi N, Denenberg A, Wong HR (2001) The serine/threonine phosphatase, PP2A: endogenous regulator of inflammatory cell signaling. J Immunol 166:966-972.

Sontag E, Luangpirom A, Hladik C, Mudrak I, Ogris E, Speciale S, White CL 3rd (2004a) Altered expression levels of the protein phosphatase 2A ABalphaC enzyme are associated with Alzheimer disease pathology. J Neuropathol Exp Neurol 63:287-301.

Sontag E, Hladik C, Montgomery L, Luangpirom A, Mudrak I, Ogris E, White CL 3rd (2004b) Downregulation of protein phosphatase 2A carboxyl methylation and methyltransferase may contribute to Alzheimer disease pathogenesis. J Neuropathol Exp Neurol 63:1080-1091.

Strack S, Westphal RS, Colbran RJ, Ebner FF, Wadzinski BE (1997) Protein serine/threonine phosphatase 1 and $2 \mathrm{~A}$ associate with and dephosphorylate neurofilaments. Brain Res Mol Brain Res 49:15-28.

Su X, Maguire-Zeiss KA, Giuliano R, Prifti L, Venkatesh K, Federoff HJ (2008) Synuclein activates microglia in a model of Parkinson's disease. Neurobiol Aging 29:1690-1701.

Swingle M, Ni L, Honkanen RE (2007) Small-molecule inhibitors of ser/thr protein phosphatases: specificity, use and common forms of abuse. Methods Mol Biol 365:23-38.

Szczypka MS, Kwok K, Brot MD, Marck BT, Matsumoto AM, Donahue BA, 
Palmiter RD (2001) Dopamine production in the caudate putamen restores feeding in dopamine-deficient mice. Neuron 30:819-828.

Tansey MG, Goldberg MS (2010) Neuroinflammation in Parkinson's disease: its role in neuronal death and implications for therapeutic intervention. Neurobiol Dis 37:510-518.

Theodore S, Cao S, McLean PJ, Standaert DG (2008) Targeted overexpression of human alpha-synuclein triggers microglial activation and an adaptive immune response in a mouse model of Parkinson disease. J Neuropathol Exp Neurol 67:1149-1158.

Tolstykh T, Lee J, Vafai S, Stock JB (2000) Carboxyl methylation regulates phosphoprotein phosphatase $2 \mathrm{~A}$ by controlling the association of regulatory B subunits. EMBO J 19:5682-5691.

van Eersel J, Ke YD, Liu X, Delerue F, Kril JJ, Götz J, Ittner LM (2010) Sodium selenate mitigates tau pathology, neurodegeneration, and functional deficits in Alzheimer's disease models. Proc Natl Acad Sci U S A 107:13888-13893.

Wu J, Tolstykh T, Lee J, Boyd K, Stock JB, Broach JR (2000) Carboxyl methylation of the phosphoprotein phosphatase $2 \mathrm{~A}$ catalytic subunit promotes its functional association with regulatory subunits in vivo. EMBO J 19:5672-5681.

Xing Y, Xu Y, Chen Y, Jeffrey PD, Chao Y, Lin Z, Li Z, Strack S, Stock JB, Shi Y (2006) Structure of protein phosphatase 2A core enzyme bound to tumor-inducing toxins. Cell 127:341-353.

Xing Y, Li Z, Chen Y, Stock JB, Jeffrey PD, Shi Y (2008) Structural mechanism of demethylation and inactivation of protein phosphatase $2 \mathrm{~A}$. Cell 133:154-163.

Yavich L, Tanila H, Vepsäläinen S, Jäkälä P (2004) Role of alpha-synuclein in presynaptic dopamine recruitment. J Neurosci 24:11165-11170.

Yu XX, Du X, Moreno CS, Green RE, Ogris E, Feng Q, Chou L, McQuoid MJ, Pallas DC (2001) Methylation of the protein phosphatase 2A catalytic subunit is essential for association of $\mathrm{B} \alpha$ regulatory subunit but not SG2NA, striatin, or polyomavirus middle tumor antigen. Mol Biol Cell 12:185-199.

Zhang W, Yang J, Liu Y, Chen X, Yu T, Jia J, Liu C (2009) PR55 alpha, a regulatory subunit of PP2A, specifically regulates PP2A-mediated $\beta$-catenin dephosphorylation. J Biol Chem 284:22649-22656. 